Jurnal Geocelebes Vol. 1 No. 1, April 2017, Hal 13 - 16

\title{
DIFRAKSI DAN EFEK SMILING PADA DATA SEISMIK
}

\author{
Johanes Gedo Sea, Yusuf Surachman Djajadihardja ${ }^{\left(1^{*}\right)}$, Muh. Altin Massinai ${ }^{(2)}$, \\ Sabrianto Aswad ${ }^{(2)}$ \\ ${ }^{(1)}$ Badan Pengkajian dan Penerapan Teknologi (BPPT) \\ ${ }^{(2)}$ Program Studi Geofisika, Universitas Hasanuddin, Makassar \\ *Penulis koresponden. Alamat email: iyung24@gmail.com
}

\begin{abstract}
Abstrak
Difraksi dan efek smiling merupakan artefak yang sering terdapat pada data seismik. Difraksi timbul pada data sebelum dilakukan proses migrasi sedangkan efek smiling timbul setelah dilakukan proses migrasi. Dalam penelitian ini akan dibahas efek smiling pada penampang hasil migrasi yang pada wilayah tersebut merupakan tempat terjadinya difraksi sebelumnya.
\end{abstract}

Kata Kunci: Difraksi, Efek Smiling, Migrasi

\begin{abstract}
Diffraction and smiling are the two effects that often present in a seismic data. Diffraction occurs before the migration process, while the smiling occurs after the migration process. This research will discuss the effect of smiling on a cross section of the result of migration, which is the diffraction happened in an area of investigation
\end{abstract}

Keywords: Diffraction, Smiling Effect, Migration

\section{Pendahuluan}

\section{Difraksi Gelombang Seismik}

Ketika bidang reflektor memiliki kelengkungan yang besar dibandingkan dengan kelengkungan muka gelombang seismik, maka perubahan kearah propagasi tidak dapat dijelaskan dengan hukum refleksi dan refraksi yang sederhana. Fenomena ray bending yang disebabkan oleh pengaruh bidang reflektor disebut difraksi, dan gelombang yang meninggalkan bidang reflektor setelah kejadian disebut gelombang difraksi. Jika bidang reflektor sangat kecil (lebih kecil dari panjang gelombang seismik), gelombang difraksi memancar ke segala arah di sekitar bidang reflektor (Al-Sadi, 1980).

Prinsip Huygens dapat digunakan untuk membangun muka gelombang difraksi. Semua titik point dari bidang reflektor dianggap sebagai titik sumber untuk wavelet sekunder. Muka gelombang difraksi pada waktu perekaman didefinisikan oleh envelope dari semua wavelet ini. Ketika gelombang bergerak, semua tipe gelombang 
seismik adalah diffractable. Contoh umum difraksi adalah kasus dimana gelombang bidang (gelombang langsung, refleksi, dan transmisi) memenuhi batas permukaan reflektor. Dalam hal ini gelombang difraksi akan bergerak jauh dari diskontinuitas ke berbagai arah sehingga menyebabkan pola interferensi dengan semua gelombang berjalan yang lain (Al-Sadi, 1980; Sheriff dkk, 1995).
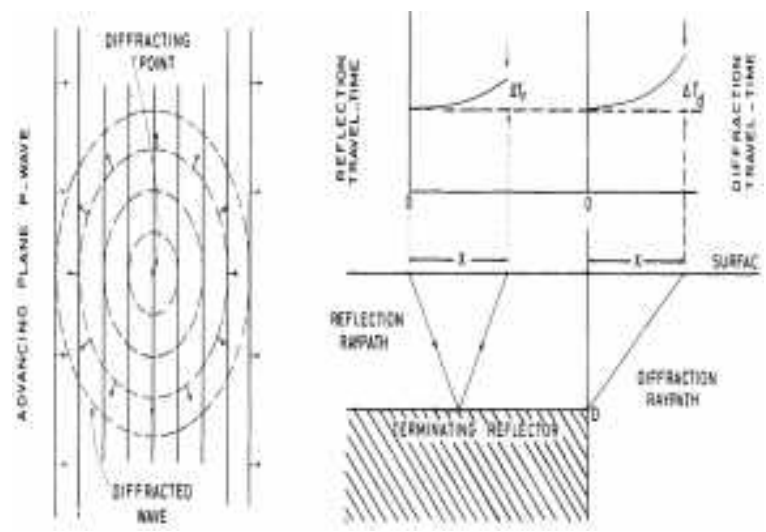

Gambar 1 Contoh difraksi. (a) Sebuah difraksi gelombang bidang dari titik, (b) Ray-diagram difraksi gelombang bidang dari ujung akhir reflektor (AlSadi, 1980)

Pada rekaman seismik, pemisahan difraksi dari fasa gelombang lainnya atas dasar karakter gelombang sulit untuk dilakukan. Namun, waktu tempuh yang berbeda dari jenis lain pada gelombang dianggap sebagai kriteria yang baik digunakan untuk mengidentifikasi difraksi. Waktu tempuh difraksi ditentukan dengan persamaan

$$
T_{x}=\frac{1}{v}\left(z+\sqrt{x^{2}+z^{2}}\right)
$$

Dimana sumber difraksi (titik D pada gambar II.8b) terletak secara vertikal di bawah sumber seismik. $T_{0}$ merupakan dua kali waktu penjalaran gelombang secara vertikal dan $T_{x}$ dapat dinyatakan kembali sebagai

$$
T_{x}=\sqrt{\left(\frac{x}{v}\right)^{2}+\left(\frac{T_{\mathrm{u}}}{2}\right)^{2}}+\frac{T_{\mathrm{u}}}{2}
$$

Untuk kejadian yang sama, waktu penjalaran gelombang refleksi diberikan oleh:

$$
T_{x}=\sqrt{\left(\frac{x}{v}\right)^{2}+T_{v}^{2}}
$$

Dengan membandingkan persamaan (II.30) dan (II.31), dapat terlihat bahwa gelombang difraksi selalu tiba pada waktu gelombang refleksi. Pengecualian untuk aturan ini adalah titik yang bertepatan dengan sumber seismik yaitu pada saat $x=0$. Pada titik ini kedua gelombang tiba pada waktu yang sama.

\section{Efek Smiling}

Efek smiling adalah efek gelombang yang membentuk kurva di sepanjang penampang dimana energi pada setiap titik penampang non-zero offset menjadi smeared ketika dipetakan kedalam zero offset. Pada Gambar 2, operator smear memetakan impuls dititik $\left(y, t_{h}\right)$ pada penampang finite-offset diatas smiling di bidang $(x, t)$ pada penampang zero offset, dan smiling membentuk segmen bawah elips. Dari gambar II.10 diperoleh (Upadhyay, 2004)

$$
\frac{(x-y)^{2}}{h^{2}}+\frac{t^{2}}{t_{v}^{2}}=1
$$

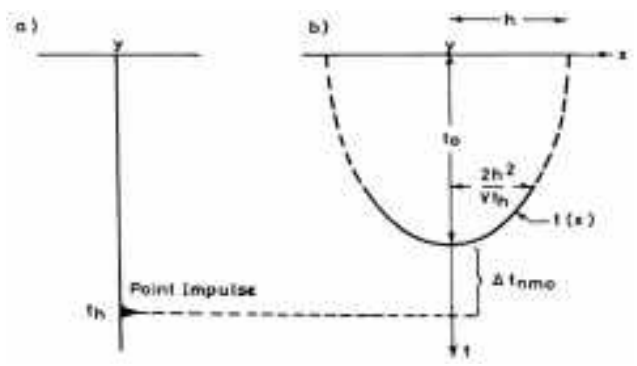

Gambar 2 Titik tunggal pada penampang finiteoffset yang memetakan efek smiling pada penampang zero-offset. (a) Trace untuk finite-offset $2 h$, (b) hasil pemetaan zero-offset (Upadhyay, 2004) 
Lokasi terjadinya smear di bidang $(x, t)$ diperoleh dengan memecahkan persamaan elips untuk $t(x)$ yaitu

$$
\tau(x)=\tau_{\mathrm{U}}\left[1-\frac{(x-y)^{2}}{h^{2}}\right]^{\frac{1}{2}}
$$

Dimana

$$
|x-y|<\frac{2 h^{2}}{V t_{h}}
$$

Dari persamaan diatas, terlihat bahwa efek smiling dipengaruhi oleh kecepatan dan posisi reflektor. Penampang migrasi yang mengalami efek smiling terjadi karena data seismik yang telah berada pada kondisi zero offset, setelah dimigrasi berada pada kondisi non-zero offset karena pengaruh kecepatan yang digunakan lebih besar dari kecepatan yang sebenarnya.

\section{Difraksi Pada Data Seismik Sebelum Migrasi}

Penampang seismik pada Gambar 3 memperlihatkan efek difraksi dominan pada reflektor bagian atas data. Reflektor bagian atas ini merupakan dasar laut dari lokasi akuisisi data seismik yang memiliki struktur kompleks sehingga menghasilkan efek difraksi tersebut. Gelombang difraksi yang terekan dipermukaan laut hanya sebagian diterima oleh receiver dan sebagiannya lagi terhalangi oleh struktur disekitarnya sehingga difraksi pada penampang ini sebagian besar berbentuk setengah parabola. Waktu tempuh gelombang difraksi sangat bergantung pada medan kecepatan struktur yang dilewati serta jarak tempuhnya sehingga atenuasi difraksi dengan migrasi bergantung pada model kecepatan yang digunakan.

\section{Efek Smiling Pada Data Seismik Setelah Migrasi}

Migrasi yang digunakan dalam penelitian ini adalah Steep Dip Explicit FD Time Migration dan Fast Explicit FD Time
Migration. Migrasi ini memanfaatkan prinsip downward continuation untuk mendefinisikan setiap aproksimasi gelombang upcoming yang digunakan untuk menentukan titik reflektor yang sebenarnya. Hasil yang diperoleh menunjukan bahwa algoritma kedua migrasi ini menghasilkan efek smiling pada lokasi yang sama dengan lokasi terjadinya difraksi.

Efek smiling yang muncul sebagian besar pada reflektor yang mengalami difraksi sehingga penampang seismik yang dihasilkan setelah proses migrasi memiliki artefak. Efek smiling dalam kasus ini terjadi akibat kecepatan yang digunakan lebih besar dari kecepatan yang sebenarnya sehingga data yang berada pada kondisi zero offset menjadi kondisi non-zero offset. Perubahan kondisi inilah yang menyebabkan terjadi overmigrasi.

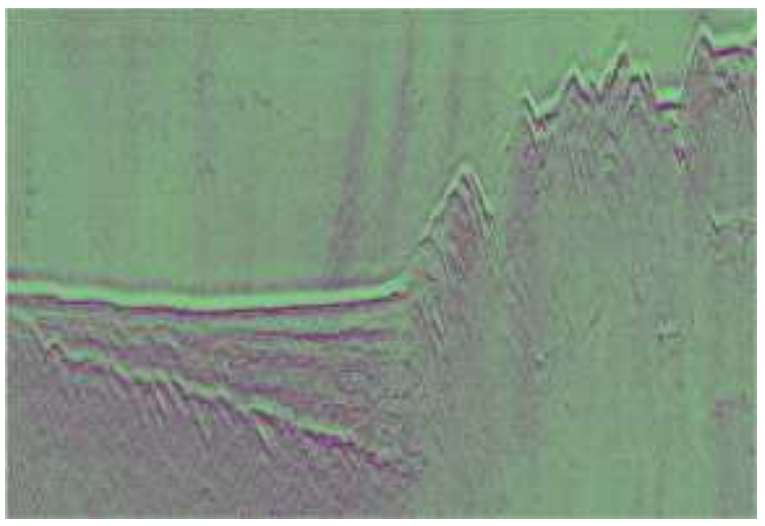

Gambar 3 Penampang sebelum migrasi

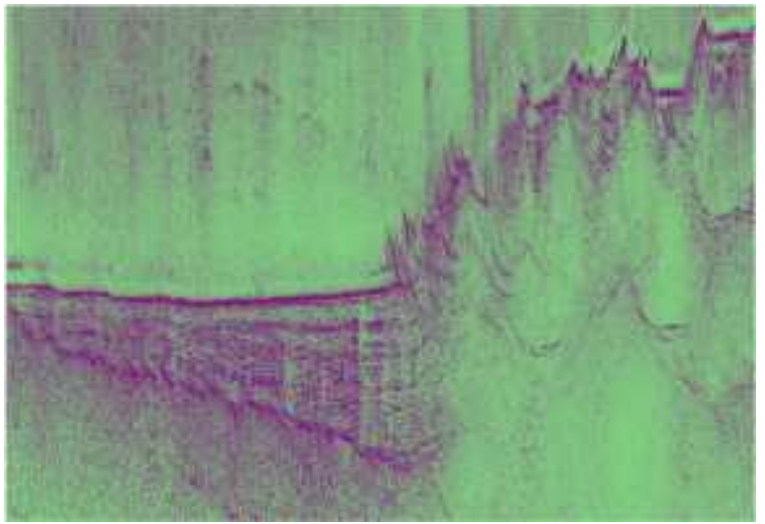

Gambar 4 Penampang hasil dari Steep Dip Explicit FD Time Migration 


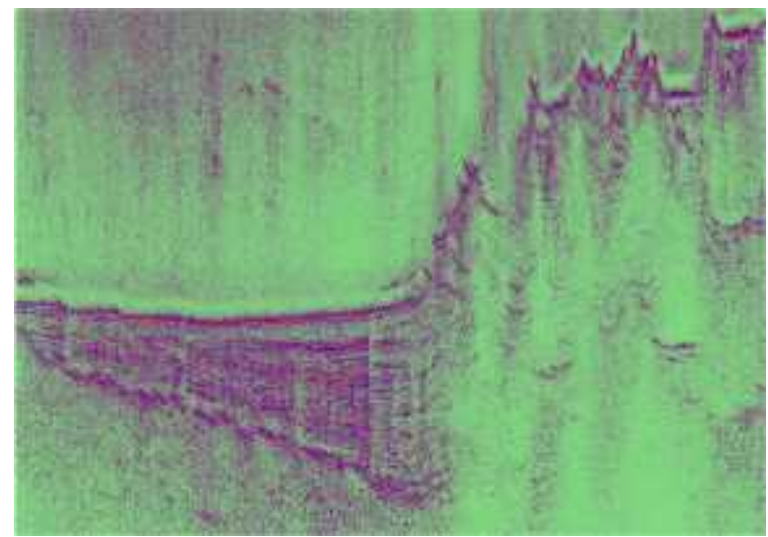

Gambar 5 Penampang hasil dari Fast Explicit FD Time Migration

\section{Pembahasan}

Difraksi dan efek smiling adalah dua hal yang berbeda. Smiling tidak ditimbulkan oleh gelombang difraksi akibat overmigrasi tetapi akibat berubahnya posisi reflektor utama dari zero offset menjadi non-zero offset akibat overmigrasi, sedangkan difraksi merupakan efek penghamburan gelombang utama pada kondisi zero offset. Meskipun penampang hasil migrasi menunjukkan adanya smile pada lokasi difraksi penampang sebelum migrasi namun smile akibat penentuan model kecepatan yang tidak sesuai pada lokasi difraksi berbeda envelope gelombang dengan difraksi baik sebelum maupun setelah migrasi. Migrasi dengan algoritma Steep Dip Explicit FD Time Migration tidak maksimal menangani difraksi dari penampang sebelumnya. Namun berbeda dengan proses migrasi Fast Explicit FD Time Migration, dimana algoritma migrasi ini berhasil mengkolapskan beberapa difraksi pada penampang yang dihasilkan dan tidak menimbulkan smiling pada beberapa reflektor.

\section{Kesimpulan}

Kesimpulan dari penelitian ini adalah
1. Difraksi merupakan artefak yang muncul pada struktur geologi yang kompleks.

2. Efek smiling timbul pada data hasil migrasi akibat penentuan model kecepatan yang tidak maksimal

\section{Daftar Pustaka}

Al-Sadi, H. N.. 1980. Seismic Exploration Technique and Processing. Springer Basel AG: Swiss.

Claerbout, J. F. 1985. Fundamentals of Geophysical Data Processing. Blackwell Scientific Publications.

Claerbout, J. F. 1996. Imaging The Earth's Interior. Cecil and Ida Green Professor of Geophysics: Stanford University.

Nejati, M. dan Hosein H.. 2012. Migrated Exploding Reflectors In Evaluation of Finite Difference Solution For Inhomogeneous Seismic Models. Scientific Research, Engineering, 2012, 4, 950-957. Published Online December 2012.

Plessix, R.E., W.A. Mulder, Shell Int'l E\&P, R.G. Pratt. 2001. Frequency-Domain Finite Difference Migration With Only Few Frequencies?. SEG Int'1 Exposition and Annual Meeting: San Antonio, Texas

Sheriff, R. E. dan Lloyd P. G.. 1995. Exploration Seismology. Boston: Cambridge University Press.

Soubaras, R.. 1992. Explicit 3-D Migration Using Equiripple Polynomial Expansion and Laplacian Synthesis. Society of Exploration Geophysics (SEG).

Upadhyay, S.K.. 2004. Seismic Reflection Processing. Springer: Berlin.

Yilmaz, Ö. 2001. Seismic Data Analysis, Volume I. United States: Society of Exploration Geophysicist. 